\title{
Determinants of Dividends for Real Estate Sector in Jordan
}

\author{
Abdullah Yusri AL Khatib ${ }^{1}$ \\ ${ }^{1}$ Department of Islamic Banks, Faculty of Finance and Business, The World Islamic Sciences and Education \\ University, Amman, Jordan \\ Correspondence: Abdullah Yusri AL Khatib, Ph.D., Department of Islamic Banks, Faculty of Finance and \\ Business, the World Islamic Sciences and Education University, Amman, Jordan. E-mail: \\ 1.Abdullah.Finance@gmail.com
}

Received: September 20, 2020

Accepted: October 30, 2020

Online Published: November 28, 2020

doi:10.5539/ijbm.v15n12p177

URL: https://doi.org/10.5539/ijbm.v15n12p177

\begin{abstract}
This study focused on analyzing the internal and external determinants of dividends for an important sector in Jordan which is the real estate sector during 2014 - 2019. For that, dividends per share were considered as dependent variable. On the other hand, internal determinants were measured by current ratio, total assets turnover, fixed assets turnover, and working capital turnover. Also, external variables were measured by GDP growth rate, inflation consumer prices, and unemployment rate.

After conducting the statistical analysis, there was an impact of working capital turnover on dividends per share at $1 \%$ significance level. The study inferred from that there was no impact of the rest of internal and external variables on the dividends per share.

As a result from that, the study recommended real estate sector to focus on and analyze working capital turnover. Moreover, it recommended analyzing the changes in external and internal variables during the time to enhance the performance of real estate sector in Jordan.
\end{abstract}

Keywords: real estate profitability, dividends per share, internal variables, external variables, inflation, and unemployment rate

\section{Introduction}

The real estate sector in Jordan and around the world is considered one of the most vital and important investment sectors. So, many studies analyzed the financial performance and measure it by return on assets, return on equity, and dividends per share. The investors prefer dividends from the financial sectors (Ramadan, 2015).

When the financial researcher takes an analyzing look at the cumulative financial data which is issued from Amman Stock Exchange (ASE), will notice three main sectors which are financial, services, and industrial sectors. For example, the financial sector contains banks; Islamic banks; insurance companies; Islamic insurance companies; diversified financial services; and real estate sectors.

In this research we are going to analyze the determinants of dividends for real estate sector in Jordan from 2014 to 2019. For that, the dependent variable is measured by dividends per share (DPS). On the other hand, the independent variables are separated to two categories; the internal variables are current ratio, total assets turnover, fixed assets turnover, and working capital turnover.

Moreover, the external variables in this research will be Gross Domestic Product growth rate (GDP growth), inflation consumer prices, and unemployment rate as a percentage of total labor force and is modeled by International Labor Organization (ILO) estimate.

\section{Research Objectives}

The objectives of this study were to clarify and analyze the determinants of dividends per share for real estate sector in Jordan during the period 2014-2019. Real estate sector in Jordan is a part of the financial sector in the cumulative data from Amman Stock Exchange. Because of that, this study focused on the following:

1. Financial performance for real estate sector which was measured by dividends per share (DPS) as dependent variable. 
2. Internal indicators for real estate sector in Jordan which were presented by current ratio, total assets turnover, fixed assets turnover, and working capital turnover as independent variables.

3. External indicators are gross domestic product annual growth (GDP), inflation rate, and unemployment rate as a percentage of total labor force in Jordan as independent variables as well.

\section{Literature Review}

Real estate sector in Jordan is considered as a financial sector such as commercial banks, Islamic banks, insurance companies, Islamic insurance companies, and diversified financial services sectors. So, the literature review will have an overlook at the financial sectors in the previous studies. In a study about analyzing profitability in banking sector from some chosen countries (Haron, 1996), there was significant positive impact of inflation on the profits of commercial and Islamic banks which indicates the increase in inflation has a reflection on sectors profitability. In addition, Francis (2013) studied and analyzed the specific and macroeconomic determinants of commercial banks profitability in Sub-Saharan Africa and found negative effect of liquidity ratio, Gross Domestic Product (GDP), and inflation rate.

There are lots of studies about the profitability of financial sectors. In a study about the determinants of dividends per share for companies listed on the Nigerian Stock Exchange (NSE) (Oloidi and Adeyeye, 2014) the findings were current year earnings per share, and previous year dividend per share were positively significant at $1 \%$, dividend payout ratio was significant at $5 \%$, and profitability and investment were significant at $10 \%$ but investment had negative impact.

In another paper about the conceptual exposition of the effect of inflation on banks' financial performance (Umar, Maijama'a, and Adamu, 2014) that paper found two different views, the first one is the adverse and harmful effect on banking and the whole economy. While the other side of the discussion stated that, inflation increased banking performance as long as they can be able to anticipate future inflation to make better revenues and profits. Moreover, banking efficiency determinants in the Czech banking sector (Řepková, 2015) was measured by annual return was effected by negative and significant impact from GDP. Also, by evaluating the financial performance (Ganga, Kalaiselvan, and Suriya, 2015), the current ratio and working capital had positive correlation with the financial performance.

Some studies such as (Enow and Brijlal, 2016) considered dividends per share as an independent variable and analyzed its impact with earnings per share and price earnings ratio on share prices. The results of that study implied that, managers can increase and enhance the values of share prices by increasing dividends per share, earnings per share, and price-earnings ratio. Also, analyzing the financial performance is conducting for diversified sectors such as the industrial sector in Jordan (Matar, Eneizan, 2018). The researchers found positive and significant impact of liquidity on the industrial sector financial performance.

\section{Research Hypotheses}

In research hypotheses section of this study, the hypotheses will be presented as main and secondary hypotheses to clarify the results of the statistical analysis.

$\mathrm{H}_{0}$ : There was no impact of internal and external variables on real estate profitability at $\alpha \leq 0.05$ significance level for real estate sector in Jordan.

$\mathrm{H}_{0.1}$ : There was no impact of internal variables on real estate profitability at $\alpha \leq 0.05$ significance level for real estate sector in Jordan.

$\mathrm{H}_{0.1 .1}$ : There was no impact of current ratio on dividends per share at $\alpha \leq 0.05$ significance level for real estate sector in Jordan.

$\mathrm{H}_{0.1 .2}$ : There was no impact of total assets turnover on dividends per share at $\alpha \leq 0.05$ significance level for real estate sector in Jordan.

$\mathrm{H}_{0.1 .3}$ : There was no impact of fixed assets turnover on dividends per share at $\alpha \leq 0.05$ significance level for real estate sector in Jordan.

$\mathrm{H}_{0.1 .14}$ : There was no impact of working capital turnover on dividends per share at $\alpha \leq 0.05$ significance level for real estate sector in Jordan.

$\mathrm{H}_{0.2}$ : There was no impact of external variables on real estate profitability at $\alpha \leq 0.05$ significance level for real estate sector in Jordan.

$\mathrm{H}_{0.2 .1}$ : There was no impact of GDP growth rate on dividends per share at $\alpha \leq 0.05$ significance level for real estate sector in Jordan. 
$\mathrm{H}_{0.2 .2}$ : There was no impact of inflation consumer prices on dividends per share at $\alpha \leq 0.05$ significance level for real estate sector in Jordan.

$\mathrm{H}_{0.2 .3}$ : There was no impact of unemployment rate on dividends per share at $\alpha \leq 0.05$ significance level for real estate sector in Jordan.

\section{Research Variables}

The variables and data in this research were taken from the websites of the World Bank and from Amman Stock Exchange (ASE) during the period 2014 to 2019, and the explanations of them as the following:

Dividends per share (DPS): are measured by cash dividends divided by number of listed shares.

Current ratio: is measured by total currents assets divided by total currents liabilities.

Total Assets Turnover: is measured by total operating revenues divided by total assets.

Fixed Assets Turnover: is measured by total operating revenues divided by the summation of projects under construction and fixed assets.

Working Capital Turnover: is measured by total operating revenues divided by working capital. In addition, working capital is measured by total current assets minus total current liabilities.

Gross Domestic Product Growth: is an annual percentage growth rate of Gross Domestic Product at market prices based on constant local currency. GDP is the sum of gross value added by all resident producers in the economy plus any product taxes and minus any subsidies not included in the value of the products. It is calculated without making deductions for depreciation of fabricated assets or for depletion and degradation of natural resources.

Inflation Consumer Prices: as measured by the consumer price index reflects the annual percentage change in the cost to the average consumer of acquiring a basket of goods and services that may be fixed or changed at specified intervals, such as yearly.

Unemployment rate: refers to the share of the labor force that is without work but available for and seeking employment. Unemployment rate is a percentage of total labor force and is modeled by International Labor Organization (ILO) estimate.

As be noticed from figure 1 the model of this study explains the internal (current ratio, total assets turnover, fixed assets turnover, and working capital turnover) and external variables (GDP, inflation rate, unemployment rate) as independent variables, and the dependent variable which is real estate profitability and is measured by dividends per share.

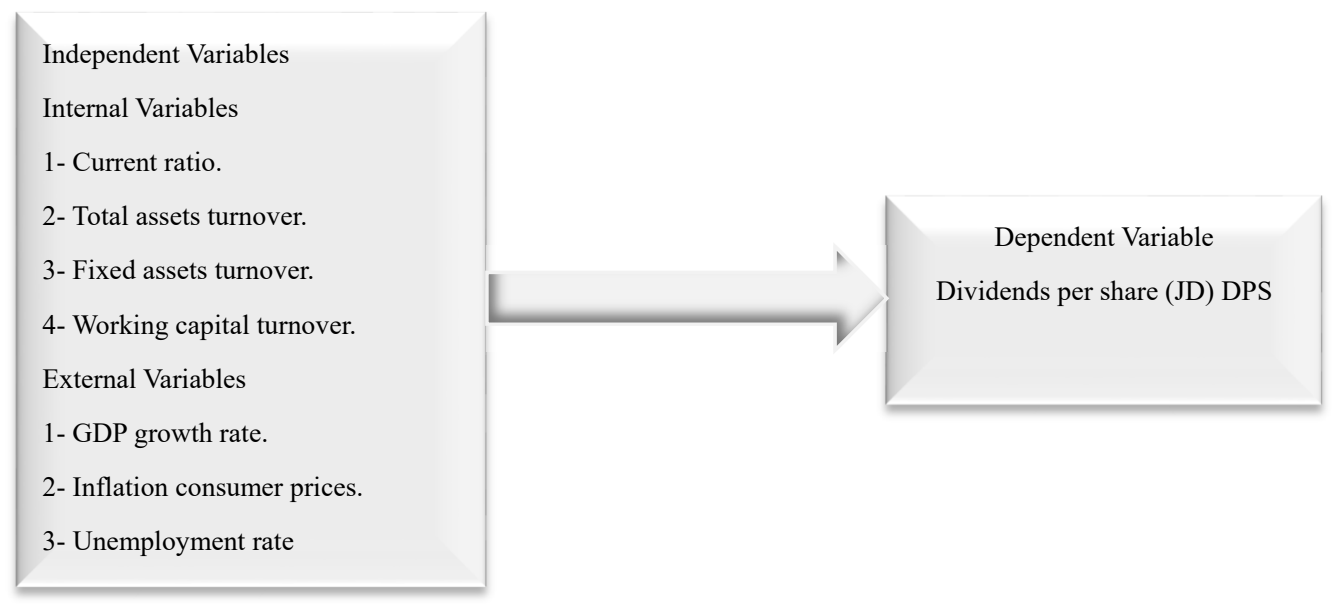

Figure 1. The independent and dependent variables

\section{Statistical Analysis}

The research calculated the correlation between the variables as be seen from table (1) Pearson correlation matrix for dividends per share (DPS) and the other variables. According to table (1) there was a positive and significant relation at (1\%) between (DPS) and each of total assets turnover and working capital turnover, and 
positive and significant relation at $(5 \%)$ with fixed assets turnover. In addition, there was negative and insignificant relation with (GDP), and positive with each of current ratio, inflation consumer prices, and unemployment rate.

The current ratio had positive and insignificant relation with inflation consumer price, and negative insignificant relation with total assets turnover, fixed assets turnover, working capital turnover, GDP, and unemployment rate. Also, fixed assets turnover had positive and significant relation at (1\%) with working capital turnover, and negative insignificant relation at $(1 \%)$ with unemployment rate. On the other hand, there was positive and significant relation at (5\%) with GDP, and negative insignificant relation with inflation.

When the reader take a look at the correlations with the working capital turnover, is going to find positive and significant relation at (5\%) with GDP, and negative significant relation at (5\%) with unemployment rate. On the other hand, there was negative and insignificant relation with inflation rate. In addition, GDP had negative and significant relation at $(1 \%)$ with unemployment rate, and positive insignificant relation with inflation rate. Finally, the correlation between inflation rate and unemployment rate was positive and insignificant level.

Table 1. Pearson correlation matrix for DPS and the other variables

\begin{tabular}{|c|c|c|c|c|c|c|c|c|c|}
\hline & DPS & Current & Total Assets & Fixed & Assets & Capital & GDP & Inflation & Unemployment \\
\hline DPS & 1 & & & & & & & & \\
\hline Current Ratio & -.532 & 1 & & & & & & & \\
\hline Total Assets Turnover & $.915^{* *}$ & -.285 & 1 & & & & & & \\
\hline Fixed Assets Turnover & $.836^{*}$ & -.084 & $.979^{* *}$ & 1 & & & & & \\
\hline Working Capital Turnover & $.948^{* *}$ & -.481 & $.977^{* *}$ & $.914^{* *}$ & & 1 & & & \\
\hline GDP growth & .592 & -.110 & $.790^{*}$ & $.802^{*}$ & & $.754^{*}$ & 1 & & \\
\hline Inflation Consumer Prices & -.458 & .221 & -.329 & -.290 & & -.340 & .097 & 1 & \\
\hline Unemployment & -.573 & -.119 & $-.834^{*}$ & $-.895^{* *}$ & & $-.743^{*}$ & $-.940^{* *}$ & .032 & 1 \\
\hline
\end{tabular}

**. Correlation is significant at the 0.01 level (1-tailed).

*. Correlation is significant at the 0.05 level (1-tailed).

As seen from table 2 the descriptive statistics of the variables, $(\mathrm{N}=6)$ which means the number of the observations is (6) values for each variable from 2014 to 2019. Also, from this table the mean and standard deviation is calculated as well. In addition, from table (3) the model summary calculated (R square) which was $(0.948)$ and that means we could explain about $(94.8 \%)$ of the variations in the dependent variable which is the real estate profitability (dividends per share DPS) in Jordan during $2014-2019$.

Table 2. Descriptive statistics

\begin{tabular}{llll}
\hline & Mean & Std. Deviation & $\mathrm{N}$ \\
\hline DPS & .012497 & .0089624 & 6 \\
Current Ratio & 1.440215 & .0596590 & 6 \\
Total Assets Turnover & .060274 & .0180417 & 6 \\
Fixed Assets Turnover & .289485 & .0833774 & 6 \\
Working Capital Turnover & .784000 & .2739416 & 6 \\
GDP growth & 2.248000 & .4486709 & 6 \\
Inflation Consumer Price & 2.183667 & 1.5941943 & 6 \\
Unemployment & 14.173167 & 1.3700701 & 6 \\
\hline
\end{tabular}

Table 3. Model summary

\begin{tabular}{llllll}
\hline Model & $\mathrm{R}$ & R Square & Adjusted R Square & $\begin{array}{l}\text { Std. Error of the } \\
\text { Estimate }\end{array}$ & \\
\hline 1 & .948 & .899 & .873 & .0031909 & \\
\hline
\end{tabular}

According to table (4) Analysis of Variance (ANOVA) for the research variables, the researcher found that (F) calculated is (35.444) at (0.004) significant level which means the model is suitable. Also, from table (5) the value of unstandardized coefficient for working capital turnover was (0.031) with standard error (0.005) and 
calculated (t) was (5.953) at (0.004) significance level which is accepted at (1\%) significance level.

Table 4. Analysis of variance

\begin{tabular}{lllllll}
\hline Model & & Sum of Squares & df & Mean Square & F & Sig. \\
\hline \multirow{3}{*}{1} & Regression & .000 & 1 & .000 & 35.444 & .004 \\
& Residual & .000 & 4 & .000 & & \\
& Total & .000 & 5 & & &
\end{tabular}

Table 5. Coefficients

\begin{tabular}{|c|c|c|c|c|c|c|}
\hline \multirow{2}{*}{\multicolumn{2}{|c|}{ Model }} & \multicolumn{2}{|c|}{ Unstandardized Coefficients } & \multirow{2}{*}{$\begin{array}{l}\text { Standardized Coefficients } \\
\text { Beta }\end{array}$} & \multirow{2}{*}{$\mathrm{t}$} & \multirow{2}{*}{ Sig. } \\
\hline & & B & Std. Error & & & \\
\hline \multirow{2}{*}{1} & (Constant) & -.012 & .004 & & -2.757 & .051 \\
\hline & Working Capital Turnover & .031 & .005 & .948 & 5.953 & .004 \\
\hline
\end{tabular}

The excluded variables as be seen from table (6), beta value for current ratio was $(-0.099)$ and the calculated $(\mathrm{t})$ was $(-0.490)$ at $(0.658)$ significance level. After that, beta value for total assets turnover was $(-0.240)$ and the calculated (t) was $(-0.281)$ at $(0.797)$ significance level. In addition beta value for fixed assets turnover was $(-0.186)$ and the calculated $(\mathrm{t})$ was $(-0.422)$ at $(0.701)$ significance level. Moreover, beta value for GDP growth rate was $(-0.284)$ and the calculated $(\mathrm{t})$ was $(-1.254)$ at $(0.299)$ significance level, and beta value for inflation consumer prices was $(-0.154)$ and the calculated $(t)$ was $(-0.882)$ at $(0.443)$ significance level. Finally, the value of beta for unemployment rate was $(0.293)$ and the calculated $(\mathrm{t})$ was 1.355$)$ at $(0.268)$ significance level.

Table 6. Excluded variables

\begin{tabular}{lllll}
\hline \multirow{2}{*}{ Model } & & Beta In & $\mathrm{t}$ & Sig. \\
\hline \multirow{2}{*}{1} & Current Ratio & -.099 & -.490 & .658 \\
& Total Assets Turnover & -.240 & -.281 & .797 \\
& Fixed Assets Turnover & -.186 & -.422 & .701 \\
& GDP growth & -.284 & -1.254 & .299 \\
& Inflation Consumer Price & -.154 & -.882 & .443 \\
& Unemployment & .293 & 1.355 & .268 \\
\hline
\end{tabular}

DPS $=\beta_{0}+\beta_{1}$ (current ratio) $+\beta_{2}$ (total assets turnover) $+\beta_{3}$ (fixed assets turnover) $+\beta_{4}$ (working capital turnover) $+\beta_{5}(\mathrm{GDP})+\beta_{6}$ (inflation) $+\beta_{7}$ (unemployment) $+\varepsilon$

DPS $=-0.012-0.099$ (current ratio) -0.240 (total assets turnover) -0.186 (fixed assets turnover) + 0.031 (working capital turnover) - 0.284 (GDP) - 0.154 (inflation) +0.293 (unemployment)

The reader can notice the trends of the research variables from figure 2 the trend of the dependent variable which is the dividends per share from 2014 to 2019. Also, figures (3), (4), (5), and (6) represent the trend of independent internal variables. In addition, figures (6), (7), and (8) represent the trend of independent external variables as well. 


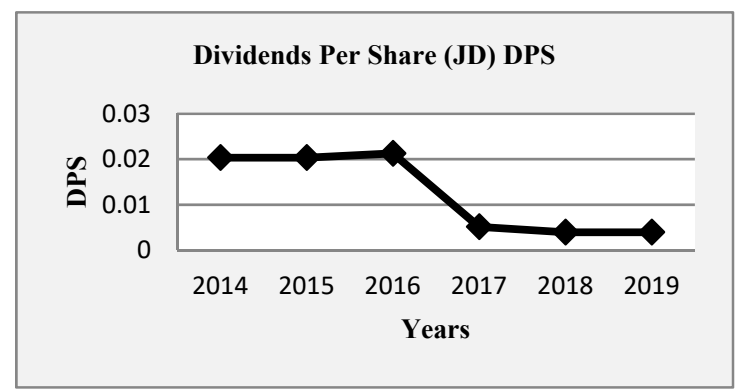

Figure 2. Dividends per share DPS during 2014 - 2019

By looking at the diagrams, the researcher estimated the values of year 2014 and the values of year 2019 to extend the period of this study and lack of information for those years. As be noticed from diagram (2) for the dependent variable is measured by dividends per share increased during 2014, 2015, and 2016 which means increasing in dividends during the time. Unfortunately, (DPS) sharply declined after that from 2017 to 2019 and that because of decreasing the dividends and increasing the shares during the time. On the other hand, diagram (3) represents the current ratio for this study, and as be seen this ratio declined from 2014 to 2016 because of increasing in total current liabilities and decreasing in total current assets. After that, current ratio increased from 2017 to 2019 because of increasing in total current assets and decreasing in total current liabilities during the time.

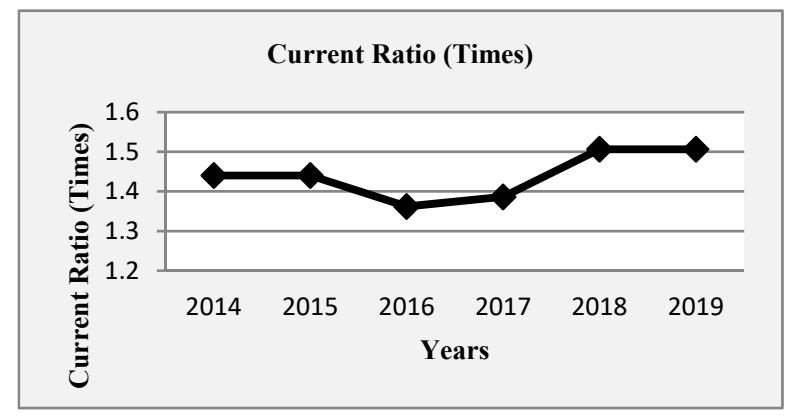

Figure 3. Current ratio during 2014-2019

Total assets turnover decreased from 2014 to 2017 which means total operating revenue is decreasing and the total assets is increasing, and after that total assets turnover became stable from 2017 to 2019 as be seen from diagram (4). Compare that with diagram (5) which represents fixed assets turnover values. As be noticed from diagram (5) fixed assets turnover decreased from 2014 to 2017 which means increasing in the values of projects under construction and fixed assets and at the same time total operating revenue is increasing. After that, fixed assets turnover increased from 2017 to 2019 and that indicates total operating revenue is increasing and projects under construction and fixed assets are increasing. Finally, working capital turnover trend is seen in diagram (6) and it decreased from 2014 to 2019 which means total operating revenue is decreasing and working capital is increasing during the time.

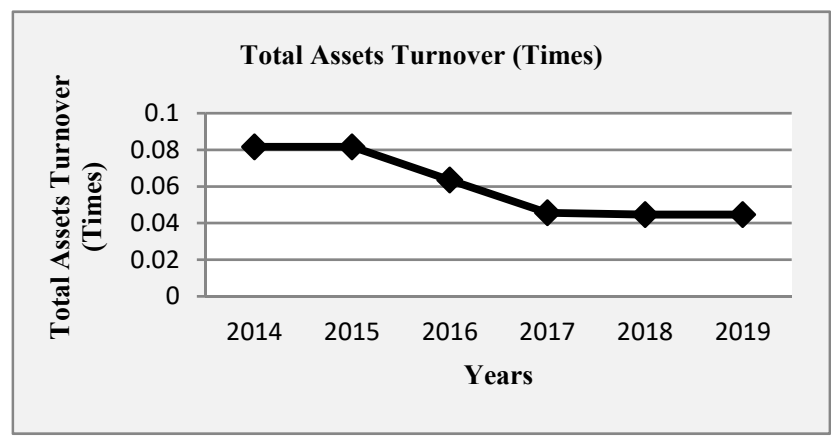

Figure 4. Total Assets Turnover during $2014-2019$ 


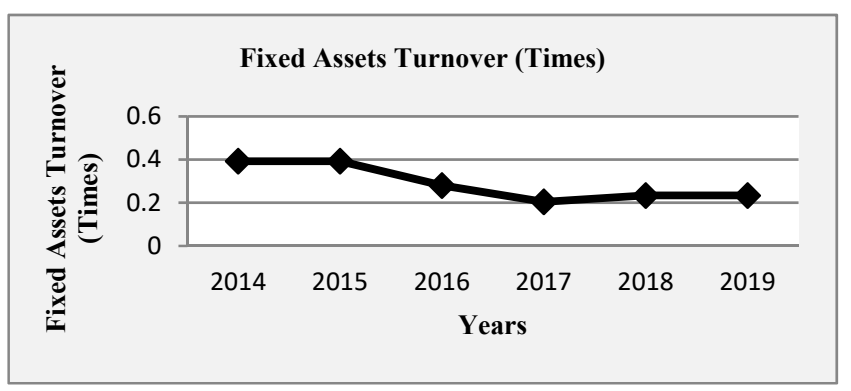

Figure 5. Fixed Assets Turnover during 2014-2019

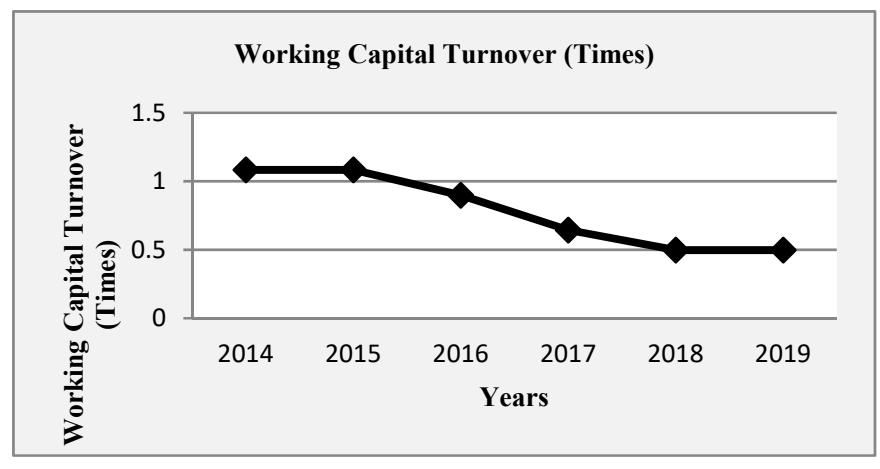

Figure 6. Working Capital Turnover during 2014-2019

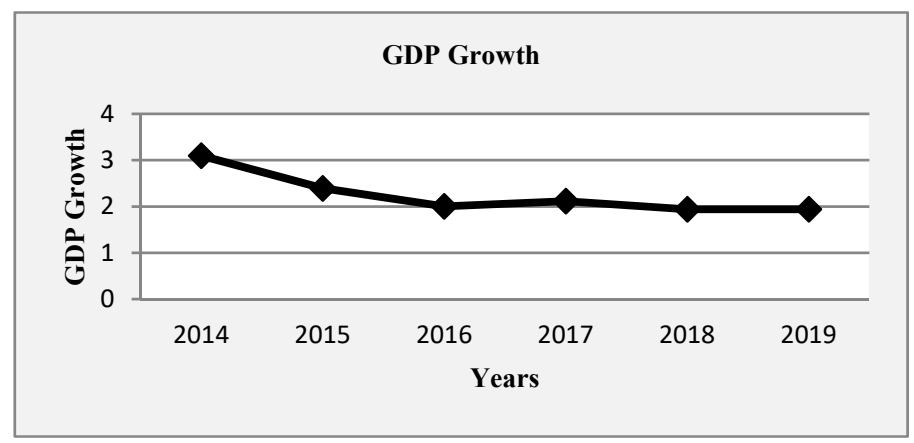

Figure 7. Gross Domestic Product Growth during 2014 - 2019

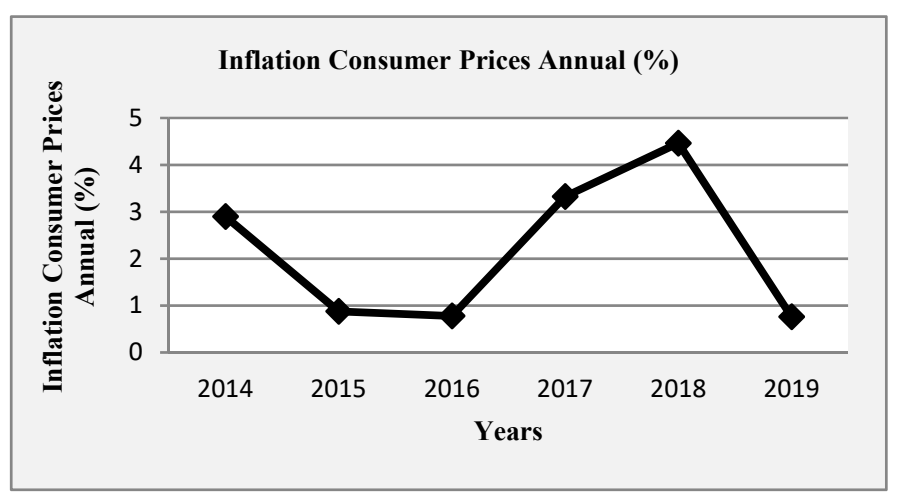

Figure 8. Inflation Consumer Prices during 2014-2019 


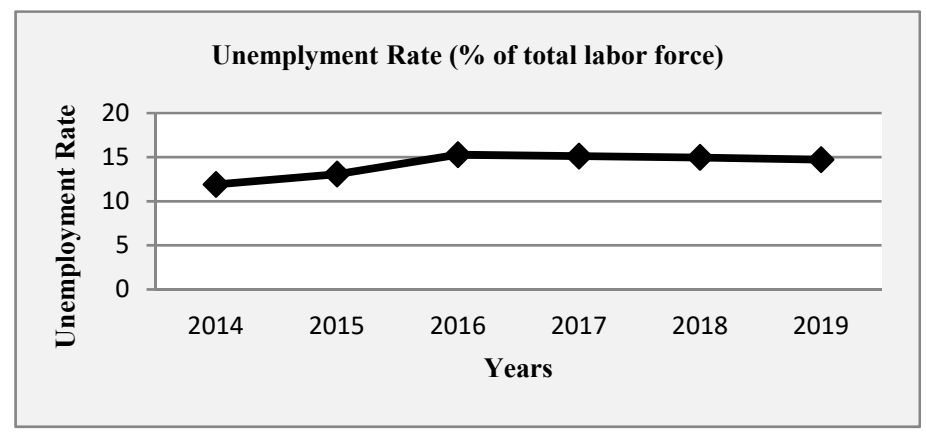

Figure 9. Unemployment rate during $2014-2019$

From figure 7 the reader can notice the trend of Gross Domestic Product growth rate (GDP growth) and notice the decline during the period of 2014 - 2016. After that, the trend of (GDP) became stable until 2019. Moreover, figure 8 represents the trend of inflation consumer prices, that trend declined from year 2014 to 2015 and became stable until 2016 and increased until year 2018 and at the end decreased in year 2019. Finally, figure 9 displays the trend of unemployment rate as can be seen; it increased from 2014 until 2016 and after that became stable until 2019. The researcher can conclude from that if unemployment rate increased, the GDP growth rate decreased and vice versa.

The reader can compare the current results of this study with other researches such as the conducting an empirical analysis for the Arabic experience (Mehta, 2012) of determinants of dividends policy from United Arab Emirates companies and analyzing the financial management and dividends payout decisions in some fields for instance real estate and construction sectors. In that research, the researcher analyzed a number of determinants such as profitability, liquidity, leverage and size of the firm. Size and profitability were found to have an impact on dividends payout decisions.

On the other hand, by making a comparison with the international experience for instance in china as analyzing the dividends policy determinants in services industry (Abbas, Ameer, 2017) for information, transportation, and communication sectors. Total revenues, total sales, earning per share, and equity played a positive impact on dividends payout ratio and dividends policy. In contrast with that, debt ratio had negative impact on dividends payout ratio and dividends policy. In addition, analyzing the dividends payout policy for manufacturing firms in Ghana (Adu-Boanyah, Ayentimi, Frank, 2013) appeared the increasing in profitability and size of the firms had positive impact on dividends payments. Also, increasing liquidity can meet the dividends payout policy and decisions.

\section{Conclusion and Recommendations}

This study focuses on real estate sector in Jordan during 2014 - 2019, the researcher found positive and significant impact of working capital turnover on dividends per share at (1\%) significant level. Moreover, the researcher found negative and insignificant impact of current ratio, total assets turnover, fixed assets turnover, gross domestic product, and inflation on dividends per share. On the other side, negative and insignificant impact of unemployment rate was found on dividends per share.

We recommend and advise real estate companies in Jordan to improve their total operating revenues and working capital to reflect that on working capital turnover and increase dividends per share annually. Also, that will enhance the prices of real estate companies' stock in Amman Stock exchange (ASE).

The officers in real estate companies must analyze and notice the insignificant variables even if they were positive or negative in this research on the long run to register the changes of these variables and if they became significant variables and had an impact on the real estate profitability during the time. 


\section{References}

Abbas, A., \& Ameer, M. (2017). Determinants of Dividends Policy in Services Industry of China. International Journal of Business, Economics, and Management Works, 4(11), 20-23.

Adu-Boanyah, E., Ayentimi, D., \& Frank, O. Y. (2013). Determinants of Dividends Payout Policy of Some Selected Manufacturing Firms Listed on the Ghana Stock Exchange. Research Journal of Finance and Accounting, 4(5).

Enow, S. T., \& Brijlal, P. (2016). Determinants of Share Prices: The Case of Listed Firms on Johannesburg Stock Exchange. Journal of Accounting and Management, 6(1).

Francis, M. (2013). Determinants of Commercial Bank Profitability in Sub-Saharan Africa. International Journal of Economics and Finance, 5(9). http://dx.doi.org/10.5539/ijef.v5n9p134

Ganga, M., Kalaiselvan, P., \& Suriya, R. (2015). Evaluation of Financial Performance. International Journal of Scientific and Research Publications, 5(4).

Haron, S. (1996). Competition and other External Determinants of the Profitability of Islamic Banks. Islamic Economic Studies, 4(1).

Matar, A., \& Eneizan, B. M. (2018). Determinants of Financial Performance in the Industrial Firms: Evidence from Jordan. Asian Journal of Agricultural Extension, Economics, and Sociology, 22(1), 1-10.

Mehta, A. (2012). An Empirical Analysis of Determinants of Dividends Policy - Evidence from the UAE companies. Global Review of Accounting and Finance, 3(1), 18-31.

Oloidi, A. G., \& Adeyeye, P. O. (2014). Determinants of Dividend per Share: Evidence from the Nigerian Stock Exchange. International Journal of Economics and Empirical Research, 2(12), 496-501.

Ramadan, I. (2015). The Jordanian Catering Theory of Dividends. International Journal of Business and Management, 10(2). http://dx.doi.org/10.5539/ijbm.v10n2p226

Řepková, I. (2015). Banking Efficiency Determinants in the Czech Banking Sector. Procedia Economics and Finance, 23, 191-196. https://doi.org/10.1016/S2212-5671(15)00367-6

Umar, M., Maijama'a, D., \& Adamu, M. (2014). Conceptual Exposition of the Effect of Inflation on Bank Performance. Journal of World Economic Research, 3(5), 55-59. https://doi.org/10.11648/j.jwer.20140305.11

\section{Copyrights}

Copyright for this article is retained by the author(s), with first publication rights granted to the journal.

This is an open-access article distributed under the terms and conditions of the Creative Commons Attribution license (http://creativecommons.org/licenses/by/4.0/). 